\title{
CARACTERIZAÇÃO DO AMBIENTE NO MUNICÍPIO DE ILHÉUS (BA): O CASO DA BAÍA DO PONTAL
}

\author{
CHARACTERIZE THE ENVIRONMENT IN ILHEUS (BA): \\ THE CASE OF THE PONTAL BAY
}

\section{CARACTERIZACIÓN DEL AMBIENTE EN LA CIUDAD DE ILHÉUS (BA): EL CASO DE LA BAHÍA DEL PONTAL}

\author{
Emilson Batista da Silva - Instituto Federal de Educação, Ciência e Tecnologia Baiano - \\ Itapetinga - Bahia - Brasil \\ emilson13@yahoo.com.br
}

\begin{abstract}
Resumo
Este artigo tem como objetivo caracterizar o estado ambiental da Baía do Pontal em Ilhéus (BA), a partir das intervenções socioespaciais. Este espaço ganha importância por ser a principal feição geomorfológica de llhéus, além de apresentar um potencial de exploração turística para o município. Utilizaram-se revisão de literatura, pesquisa de campo, imagens de satélites e entrevistas a 35 pessoas, centradas em indicadores ambientais sobre 0 estado atual da baía. Os mapas foram construídos a partir do programa Spring 5.1.6, fornecido pelo INPE, mediante a utilização de imagens de satélite do Sensor TM do LANDASAT 5. Verificou-se que as intervenções são oriundas da degradação nas bacias dos rios tributários, da construção do porto de llhéus e do processo de ocupação do entorno da baía. Consequentemente 0 ambiente apresenta transformações na morfogênese, pedogênese, vegetação e qualidade da água, que repercutem no cenário socioeconômico local por limitar sua utilização para o lazer e a fonte de renda, tanto para a subsistência da população quanto para a atividade turística. Palavras-chave: relação sociedade-natureza, Baía do Pontal, intervenções socioespaciais.
\end{abstract}

\begin{abstract}
The study aimed to characterize the environmental State of the Pontal Bay, in Ilheus (BA), from socio-spatial interventions. This place gains importance for being the main geomorphological feature of Ilheus, beyond having a potential for tourism development for the city. The study was conducted through literature review, field research, satellite images and interviews with 35 people. These instruments focused on environmental indicators about the current State of the Bay. The maps were constructed from Spring 5.1.6 program, provided by INPE, using satellite imagery Sensor TM LANDASAT 5. We found that the interventions are derived from the degradation in the basins of the tributary rivers, the construction of the Port in llheus and from the occupation process around the Bay. Thus, nowadays the environment presents some changes in morphogenesis, pedogenesis, vegetation and water quality. These changes have an impact on local socioeconomic scenary when they limit their use for recreation and as an income source not only for population livelihood, but also for the tourism.
\end{abstract}

Key words: relationship between society and nature, Pontal Bay, socio-spatial interventions.

\section{Resumen}

Lo estudio tiene como objetivo caracterizar el ambiente de la Bahía del Pontal, en llhéus (BA), a partir de intervenciones socio-espaciales. El área adquiere importancia ya que, además de constituirse como la principal configuración geomorfológica de llhéus, se representa como un potencial de desarrollo turístico para la ciudad. El estudio se realizó a través de revisión de la literatura, estudio en campo, imágenes de satélite y entrevistas a 35 personas. Estos instrumentos de estudio se han centrado en los indicadores sobre el estado actual de la Bahía. Los mapas fueron construidos a partir del programa Spring 5.1.6, proporcionado por el Instituto Nacional de Investigaciones Espaciales (INPE), utilizando las imágenes de satélite del sensor TM LANDASAT 5. Se verifica 
que las intervenciones se derivan de la degradación de las cuencas de afluentes, de la construcción del puerto de Ilhéus, así como del proceso de ocupación alrededor de la Bahía. Por lo tanto, en la actualidad el lugar presenta cambios en la morfogénesis, en la pedogénesis, en la vegetación y en la calidad del agua. Estos cambios reflejan en el contexto socioeconómico local cuando su utilización está centrada solamente en la recreación y como fuente de ingresos, tanto para los medios de vida de las personas, sino también para el turismo.

Palabras clave: relación entre la sociedad y la naturaleza, Bahía del Consejo, intervenciones socio-espaciales.

\section{Introdução}

A Baía do Pontal apresenta área de aproximadamente $16 \mathrm{~km}^{2}$ e uma altura média de maré de 1,8 m. Limita-se ao norte com a Avenida Dois de Julho (no centro de Ilhéus); ao sul com a Avenida Lomanto Junior (localizada no Bairro do Pontal); a oeste pela Ilha do Frade e a foz dos rios Cachoeira, Itacanoeira e Santana; e a leste com o Morro do Pernambuco e Oceano Atlântico (Figura 1). Trata-se de uma zona de estuário que se caracteriza como a principal feição geomorfológica do município de Ilhéus, sobretudo pela sua importância no decorrer da história econômica da região.

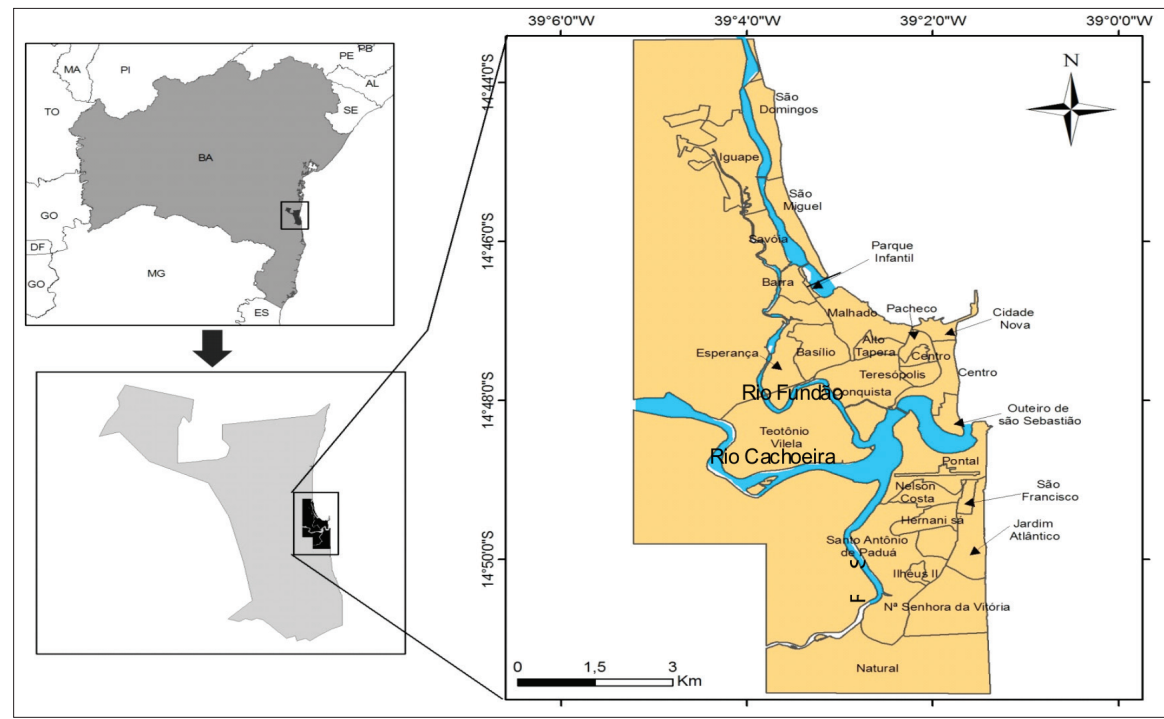

Figura 1: Localização da Baía do Pontal, Ilhéus (BA).

Para Pritchard (1952) e Cameron e Pritchard (1963), estuário é um corpo de água costeiro semifechado, com uma livre ligação com o oceano 
aberto, no interior do qual a água do mar é mensuravelmente diluída pela água doce oriunda da drenagem continental. Observa-se, assim, que se trata de um ecossistema de transição do mar com o continente.

Os estuários também são conhecidos pela sua alta produtividade biológica se comparados com os rios ou o oceano que os cercam, fazendo com que essas áreas sejam importantes para a dinâmica ambiental. Por outro lado, eles têm se constituído em lugares propícios ao desenvolvimento econômico, sobretudo para a construção de empreendimentos turísticos. Essa forma de apropriação aconteceu a partir da metade do século XIX, pois até esse período a preocupação com os estuários girava especialmente em torno da descarga de efluentes domésticos e em pequena parte da erosão nas áreas agrícolas que provocavam maior transporte de sedimentos para os rios. Sobre o assunto, Farinaccio e Tessler (2010, p. 420) afirmam:

Dentre os problemas decorrentes da ocupação de áreas costeiras destacam-se aqueles relacionados à alteração do meio físico, principalmente aqueles que interferem na dinâmica dos processos sedimentares, e de movimentação de sedimentos ao longo da costa. Muitas destas atividades antrópicas privam as costas de seu natural suprimento de areia, como as obras de regularização e estabilização de rios e a mineração em áreas fontes de sedimentos, obras portuárias, as de melhoramento de embocaduras e as de dragagens de manutenção.

Cronin (1967) concorda com a necessidade de identificar a influência da sociedade nos processos que envolvem esses espaços e de haver estudos que viabilizem uma compreensão das possíveis modificações futuras decorrentes da ação humana. Miranda, Castro e Kjerfve (2002, p. 28) afirmam que os estuários sempre foram áreas de atração econômica porque

são locais adequados para a instalação de portos; são férteis e podem produzir grandes quantidades de matéria orgânica; constituem uma via de acesso importante para o interior do continente; suas águas são renovadas periodicamente sob a influência da maré.

Todo esse patrimônio tem sido colocado em risco, já que estas áreas representam um cenário de grande atividade econômica e alta concentração populacional. No âmbito brasileiro, já foram registrados diversos estudos versando sobre a temática da ação humana nos estuários. De acordo com Pereira (1996), observa-se que, no estado de Pernambuco, a erosão marinha está causando destruição e degradação em diversos locais. Souza (2007, p. 24) afirma: 
Os fatores antrópicos envolvem as intervenções do homem nos ecossistemas costeiros. Estas intervenções estão associadas em geral à ocupação desordenada, à falta de planejamento urbano, realizando aterros indiscriminados dos mangues e de obras de engenharia como portos e marinas, que alteram profundamente o equilíbrio dos processos de transporte de sedimentos na zona litorânea.

Nesse sentido, as pressões exercidas sobre o estuário da Baía do Pontal levaram este espaço a apresentar um Estado ${ }^{1}$ que se caracteriza como um reflexo das intervenções sociais. Esse quadro nos conduz a refletir sobre a evolução desses processos de transformação, caso as Pressões ${ }^{2}$ continuem a ocorrer na mesma intensidade. Essas repercussões, em nosso caso, se apresentam na morfologia da Baía do Pontal.

Assim, o resultado das inter-relações entre as várias instâncias da sociedade emergem nessa baía como uma paisagem altamente transformada, em que as rugosidades presentes servem de orientação para o entendimento de que forma este espaço será delineado futuramente.

Os mecanismos que representam o Estado atual da baía, que estão centrados comparativamente no Estado de origem do ambiente, nos servem como um norteamento para analisar a evolução deste ambiente, sem perder de vista a dinâmica inerente a ele e a possibilidade da implementação de ações visando remediar as intervenções.

Dessa forma, este estudo pretendeu caracterizar o atual Estado da Baía do Pontal, em decorrência das intervenções implementadas pela sociedade local para garantir a reprodução de seu processo produtivo. Depreende-se que este espaço produzido se apresenta em constante readaptação às mudanças que lhe são impostas.

Material e método

A temática da pesquisa foi a relação entre a sociedade e a natureza, considerando as intervenções implementadas pela sociedade em seu ambiente para adequá-lo às suas peculiaridades produtivas. O recorte selecionado foi a Baía do Pontal, caracterizado como um sistema estuarino, localizado ao sul do município de Ilhéus (BA).

Assim, foram utilizados, como instrumentos de coletas, a revisão de literatura, o registro e a análise de imagens antigas e atuais, além da aplicação de entrevistas a 35 pessoas, divididas em quatro grupos. O primeiro foi composto por 21 moradores dos bairros do Pontal, Nova Brasília 
e da Avenida Dois de Julho, amostrados de forma aleatória, com o intuito de identificar a relação que os moradores mantêm com a Baía do Pontal (trabalho, lazer etc.), além de investigar se eles se reconhecem como parte do ambiente no qual está localizada a baía, com a finalidade de preservá-lo, de fiscalizar as ações inerentes ao poder público e de observar as transformações em curso.

O segundo grupo constou de seis pescadores, selecionados aleatoriamente, das adjacências da Baía do Pontal, com o objetivo de observar se eles percebem algum tipo de mudança no ambiente, em relação à pesca e à geomorfologia. $\mathrm{O}$ terceiro foi formado por um técnico e pela engenheira sanitarista da Empresa Baiana de Águas e Saneamento S.A. (Embasa). Buscou-se identificar as áreas nas adjacências da Baía do Pontal em que existem tratamento e destinação adequada de esgoto, e os locais onde ele é depositado diretamente na Baía do Pontal. Já o quarto grupo foi formado por três funcionários da Prefeitura Municipal de Ilhéus, um arquiteto, participante do "Projeto Orla", e dois professores de história regional, com o objetivo de investigar como se dá a fiscalização das construções no município de Ilhéus quanto à destinação de efluentes.

Todas as entrevistas foram realizadas individualmente e precedidas de agendamento. O entrevistador fazia uma breve introdução de sua pesquisa para, então, iniciar as perguntas. Os resultados destas, juntamente com os outros instrumentos, foram embasados em indicadores ambientais que refletem o atual estado da baía. São eles:

\section{Hidrodinâmica local}

A hidrodinâmica constou do levantamento dos tipos de ondas, regime de marés e circulação atmosférica na área de estudo, além do padrão de vazão dos rios tributários. Os trabalhos que subsidiaram esta etapa foram de Apoluceno (1998), Nascimento et al. (2007) Corrêa (2010) e Marques (2008). Sítios importantes foram consultados, como o do Instituto do Milênio e do Instituto Nacional de Pesquisas Espaciais (INPE). A análise da hidrodinâmica serviu para caracterizar vazões, velocidade, direção e intensidade das correntes na Baía do Pontal.

\section{Aporte de sedimentos/assoreamento}

Os trabalhos de Silva (2001) e Franco, Lavenère-Wanderley e Moreau (2006) foram utilizados na verificação do processo de assoreamento do local. A análise da variação batimétrica serviu para caracterizar a 
morfodinâmica e foi feita através, além dos trabalhos citados, mediante a carta batimétrica do ano de 1941 na escala 1/10000 (Tourinho, 1943), bem como a folha de bordo n. FB1201-004/76 na escala 1/5000, referente ao levantamento realizado pela Diretoria de Hidrografia e Navegação (DNH), em 1976. Também fez-se um registro fotográfico demonstrando a presença de bancos de areia no interior da área de estudo.

3. Crescimento da vegetação de manguezal

4. Formação de bancos de areia na Baía

\section{Prolongamento/desaparecimento de praia}

Os indicadores referentes ao crescimento da vegetação de manguezal, à formação de bancos de areia e ao prolongamento/desaparecimento de praias no interior da Baía do Pontal foram investigados a partir de pesquisa de campo, onde se realizou a observação sistemática e o registro fotográfico. Quanto ao prolongamento de praia, verificou-se o processo de formação da Praia do Cristo ao norte da área de estudo. Ao sul, estão localizadas as áreas onde se deu o desaparecimento de praia, onde a Praia do Pontal desapareceu; vale destacar que ela já não existe mais desde a década de 1960.

6. Modificação do canal de saída

O trabalho de Silva (2001) constatou, através da construção de dois perfis, que o canal de saída da Baía do Pontal se deslocou mais para o sul. Esse processo foi investigado com base no processo hidrodinâmico específico da área.

Para a construção dos mapas, foi utilizado o programa Spring 5.1.6, fornecido pelo INPE, mediante a utilização de imagens de satélite do Sensor TM do LANDASAT 5, Órbita 215, Ponto 70, com data de processamento de 14/7/2011, revolução 45566. As imagens foram adquiridas no banco de dados disponível no sítio do INPE.

\section{Situação atual da Baía do Pontal}

\section{Alterações na morfogênese local}

As alterações ocorridas nas bacias dos rios tributários da baía (rios Cachoeira, Santa e Fundão), juntamente com as mudanças nos padrões 
oceanográficos, intensificados a partir da construção do Porto de Ilhéus na Enseada das Trincheiras no bairro do Malhado, ao norte, contribuem com as transformações na Baía do Pontal.

Do ponto de vista da morfologia, verifica-se a existência de três aspectos que caracterizam o Estado desse espaço atualmente: a progradação da Praia do Cristo; o desaparecimento da Praia do Pontal; o assoreamento, que é muito perceptível através das formações arenosas presentes na foz dos rios tributários e de uma recente formação arenosa surgida no centro-leste da área no mês de marco de 2012.

De acordo com Apoluceno (1998), existe uma relação direta entre a progradação ${ }^{3}$ da Praia do Cristo, localizada no canal de saída da baía, e o desaparecimento da Praia do Pontal, que está ao sul. No caso da Praia do Cristo, a construção do Porto de Ilhéus, na Enseada do Pontal, fez com que houvesse modificações na deriva litorânea resultante potencial na saída da baía, ocasionando um aumento de $220.000 \mathrm{~m}^{3} / \mathrm{ano}$ de sedimentos depositados onde está a Praia do Cristo, consequentemente, provocando sua progradação.

Paralelo a esse processo, a aceleração do assoreamento dos rios tributários causou a diminuição do fluxo de água destes que, associada à diminuição da ação marinha no interior da baía, propiciou o aumento do aporte sedimentar na foz dos rios e as mudanças na dinâmica de circulação estuarina.

Essas transformações se desdobraram no deslocamento do canal de saída para uma porção mais ao sul da baía (Silva, 2001), extinguindo a antiga Praia do Pontal (Figura 2) e ameaçando a estrutura da Avenida Lomanto Junior. Por isso, foi construída uma contenção composta de rochas em toda a porção sul da baía, onde se localiza essa avenida.

O espaço que antes era freqüentado por muitas pessoas, tanto de Ilhéus como de outras cidades da região e do Brasil, sobretudo nos finais de semana, atualmente serve de ponto de atraque de barcos de pesca de pequeno porte. De acordo com os moradores mais antigos, além da perda da praia, surgiu ali um odor desagradável e a presença de roedores é constante.

A Figura 3 apresenta a modificação na dinâmica morfogênica, demonstrando a progradação da Praia do Cristo e as formações arenosas, decorrentes do assoreamento da baía. Exceto a Praia do Cristo, que apresenta uma face de praia permanente, todos os outros locais representados ficam à mostra no período de maré baixa, momento em que a navegação na baía fica restrita a algumas áreas, mesmo com embarcações mais simples. 


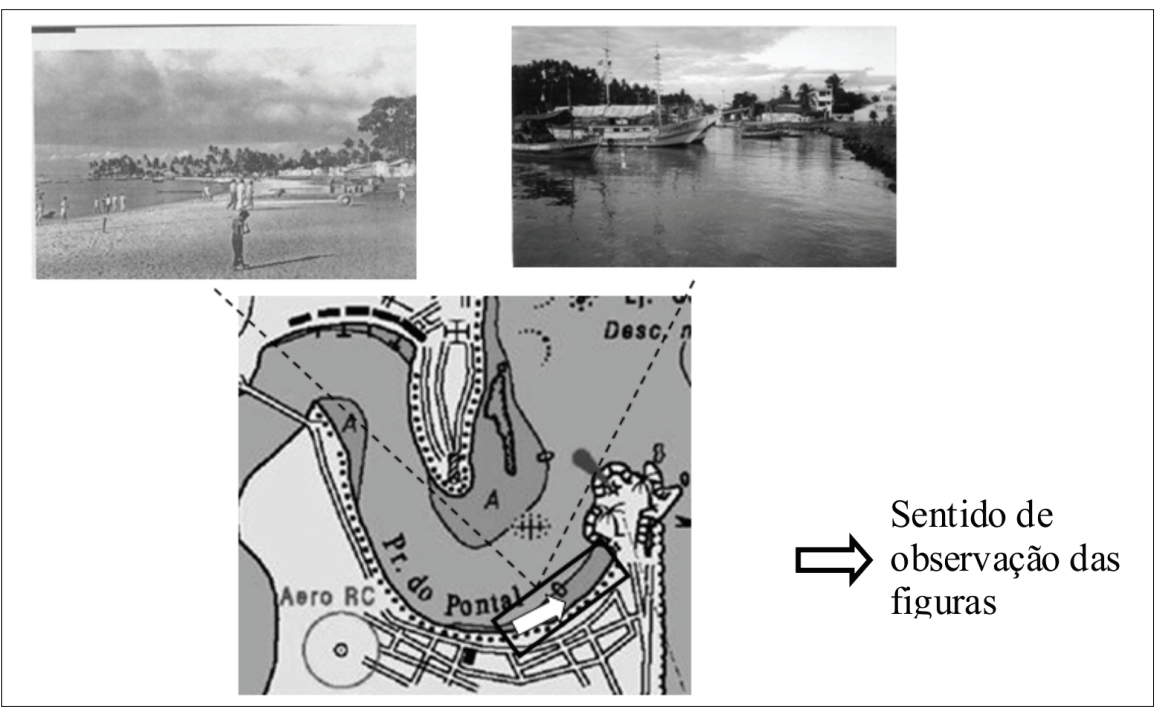

Figura 2: Antiga Praia do Pontal na década de 1960 e na atualidade.

Fonte: Jornal Agora, junho de 2002; Silva (2001).

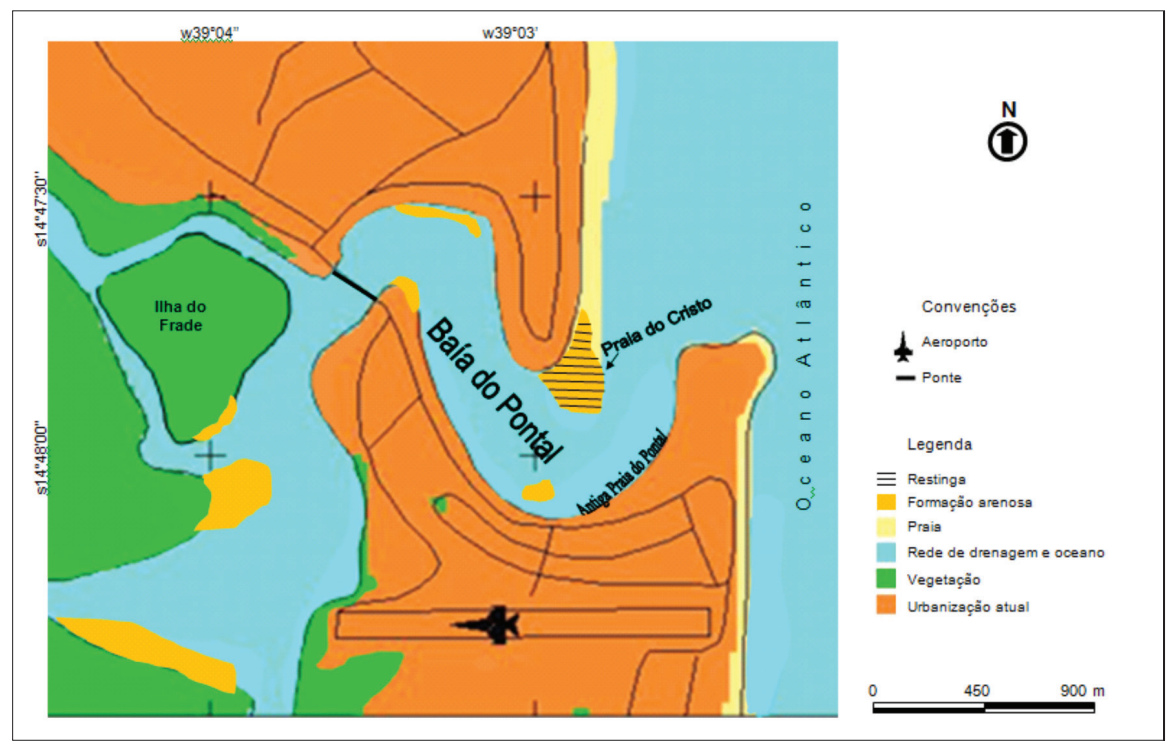

Figura 3- Caracterização do Estado da morfogênese na Baía do Pontal, Ilhéus (BA).

Elaboração: Olga Oliveira; Emilson Batista da Silva (2012). 


\section{Modificações pedológicas e da cobertura vegetal}

As observações em campo permitiram constatar que os mangues estão se disseminando na porção oeste e sul da baía. A diminuição da capacidade de transporte sedimentar no interior da área de estudo e o aumento da deposição de sedimentos ocasionaram a intensificação do processo de assoreamento. Em decorrência disso, os depósitos sedimentares dos rios tributários não são carreados efetivamente para fora da baía, eles são depositados no interior da área, originando formações arenosas e solos lamosos, ideais para a constituição dos mangues (Figuras 4A e 4B). Além de possibilitar a formação de mangues, esse fato propicia a ampliação deles, já existentes na foz dos rios que deságuam na Baía do Pontal (Figura 4C).

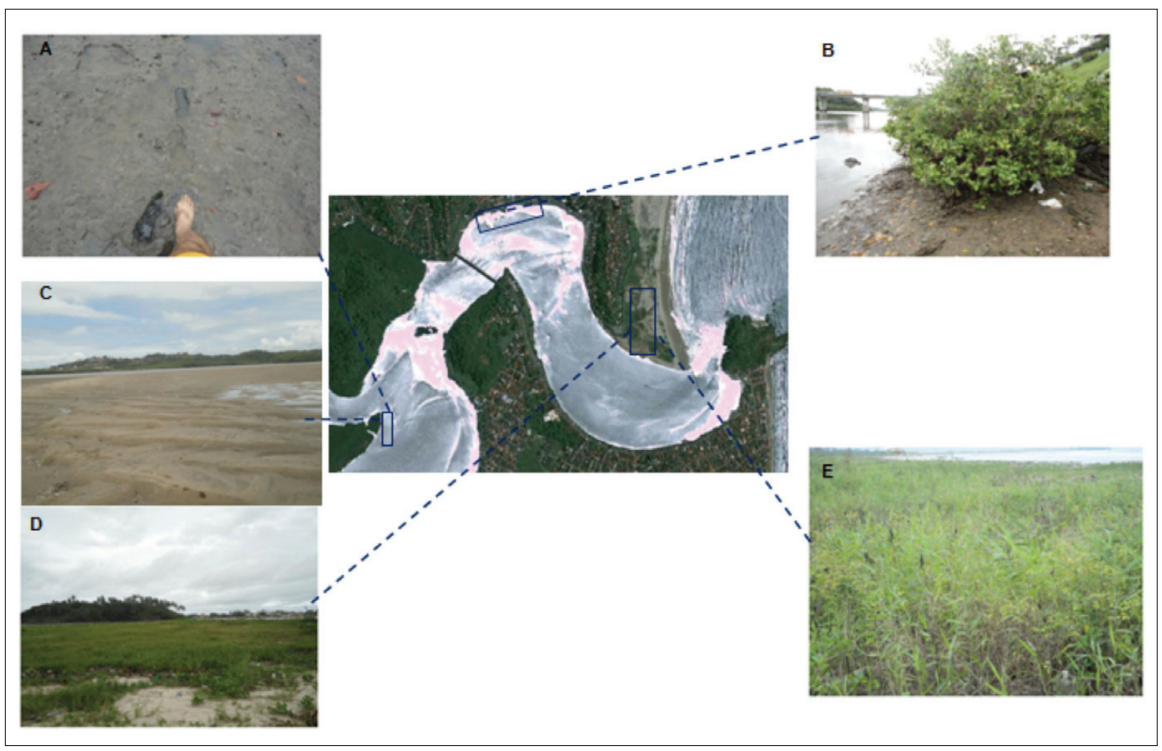

Figura 4A e C - Depósito fluvial propício à formação de mangues; B: Área de propagação de mangue; D e E: Formação de restinga na Praia do Cristo.

Fonte: Google Earth; Emilson Batista da Silva (2012).

A presença dessa cobertura vegetal poderá comprometer a utilização da área para a atividade turística, especialmente em razão do forte odor decorrente da grande quantidade de matéria orgânica em decomposição típica dos ambientes onde normalmente se localiza essa vegetação. 
De acordo com os pescadores entrevistados, parte dessa vegetação, sobretudo a sudoeste da baía, é retirada ("podada") em determinados períodos do ano, quando estão muito altas, dificultando a circulação de pessoas e a contemplação da Baía do Pontal pelos visitantes, pois a Avenida Lomanto Junior é a via com maior fluxo de veículos, principalmente no período de alta estação.

Na Praia do Cristo, a formação de um terraço arenoso bem desenvolvido e consolidado, oriundo do processo de deposição marinha, possibilitou a formação da restinga, onde se verifica a colonização por espécies herbáceas (Figuras 4D e 4E).

Modificações nos padrões de qualidade da água

A quantidade de efluentes lançados no sistema, isto é, nas bacias dos rios tributários, bem como no estuário da Baía do Pontal, juntamente com as partículas biogeoquímicas oriundas de suas adjacências e do transporte realizado pelo oceano, comprometem sobremaneira a qualidade da água na baía.

Para Sperling (1996), os cursos hídricos têm a capacidade de autodepuração, ou seja, toda a matéria depositada na água sofre um processo natural de neutralização, em que a diluição, a sedimentação e a estabilização bioquímica (decomposição do material orgânico) são os elementos principais. A atuação dos microrganismos (aeróbicos) demanda a presença de oxigênio dissolvido na água, porém a presença de matéria orgânica na água leva à diminuição dos níveis de oxigênio dissolvido, já que este é consumido pelos microrganismos para a decomposição da matéria orgânica. Esse fato pode ocasionar sérios danos para a fauna e a flora do curso hídrico, podendo provocar, principalmente, a morte de peixes.

Verifica-se que a Baía do Pontal já demonstra tais efeitos, pois, segundo os pescadores, a quantidade de peixes e mariscos vem decaindo, o que os leva a buscar outras fontes de renda. Em virtude disso, uma parcela dos pescadores moradores do Banco da Vitória, a aproximadamente cinco quilômetros da foz do rio Cachoeira, desce o rio em determinados períodos para pescar na Baía do Pontal, principalmente na foz dos rios tributários. 
A influência do processo de ocupação no estado da baía do pontal

O entorno da Baía do Pontal é possuidor de uma urbanização centrada nos aspectos residencial, comercial, de lazer, turismo, pesca e esportes náuticos (Figura 5). Observa-se a presença de calçadões, jardins, bares, restaurantes e monumentos históricos, que propiciam uma área de contemplação da paisagem. Soma-se a isso o fato de a Baía do Pontal se caracterizar como um ponto de encontro noturno para os moradores e visitantes, além de serem realizados eventos importantes da cidade em suas imediações, como festas culturais e provas esportivas.

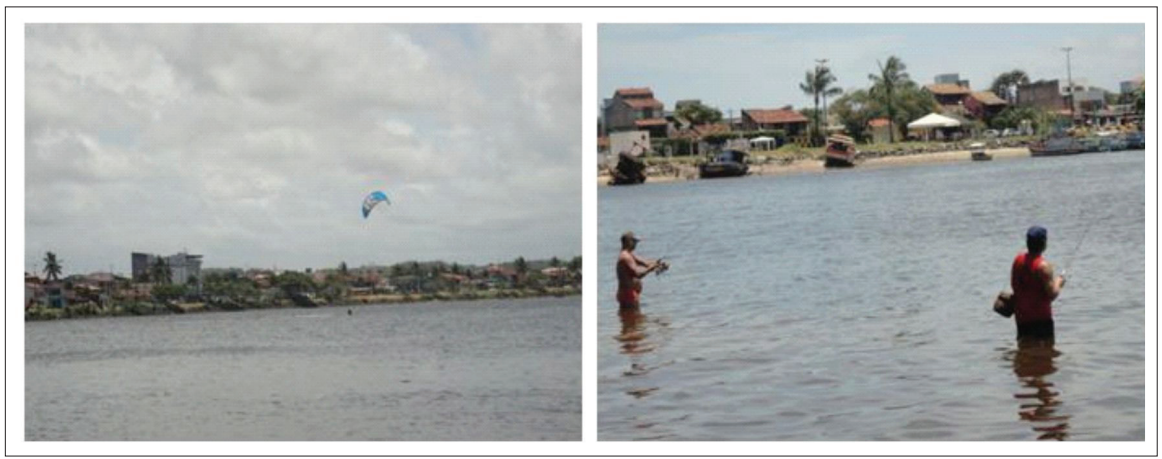

Figura 5 - Prática de esportes náuticos e da pesca artesanal na Baía do Pontal.

Fonte: Emilson Batista da Silva (2011).

Existem muitos problemas nos bairros adjacentes à Baía do Pontal, que se desdobram em consequências ambientais para os processos existentes no estuário da baía. No bairro do Pontal, ao sul, os moradores entrevistados afirmaram que a falta de investimento do poder público na infraestrutura é o maior problema enfrentado por eles, especialmente em relação ao esgotamento sanitário que é feito por meio de fossas. Um dos entrevistados afirmou que, no período de maré alta, sente o forte odor vindo dos banheiros de sua casa.

No bairro Nova Brasília, a leste, a grande queixa é a deposição de lixo de forma irregular, piorando com a negligência do poder público em manter aquele espaço limpo. Quanto às mudanças ocorridas nessa área, os moradores afirmaram que sentem falta da Prainha (praia muito frequentada antes das mudanças geomorfológicas), quando não existia a de- 
posição de areia que atualmente se faz presente e o fluxo de pessoas era muito intenso.

Esse contexto nos possibilita verificar que existem sérios problemas em relação à ocupação do entorno da baía, como a insuficiência do saneamento básico, as ligações clandestinas de esgoto, que extravasam na área, a deterioração urbana e poluição da baía com a deposição de resíduos sólidos nas margens e de efluentes nas águas (Ilhéus, 2007).

Percebe-se que, no Morro do Pernambuco, a leste, o acesso inadequado de veículos, a deposição de lixo e a tendência erosiva, devido à acentuada declividade, justificam a perda do horizonte orgânico do solo em alguns locais.

Segundo os moradores entrevistados, no Morro do Pernambuco na Bica do Morro do Pernambuco -, era extraída a água potável que a população local utilizava no início da ocupação da baía. Esta água era vendida de casa em casa no lombo de animais.

Atualmente, os moradores não a utilizam mais, pois se apresenta inadequada para o consumo humano. Nesse morro, observa-se a falta de conservação do farol e do mirante ali existentes e a carência de infraestrutura de apoio ao visitante. Além de contribuir com a degradação, esse fato ocasiona a redução do fluxo de turistas que, nos últimos anos, apenas passam pelo lugar com o fim de fotografar e observar rapidamente as rochas vulcânicas que embelezam a paisagem (Figura 6).

De acordo com Lacerda et al. (2006, p. 6), "a poluição visual de alguns morros do entorno [da Baía do Pontal], resultado da ocupação desordenada e carência de infraestrutura, é outro agravante para o turismo. Este cenário contribui para o comprometimento do desenvolvimento da região".

Quando se analisa o mapa de uso da terra da área de estudo (Figura 7), percebe-se que a vegetação original dessa área é do tipo floresta perenifólia latifoliada higrófila hileana (Santana et al., 2003, p. 15) que, como verifica-se, existe em poucos locais. Essa questão está associada à forma predatória que caracterizou o processo de ocupação, com a retirada da mata para a prática do extrativismo vegetal em busca de madeira e da exploração de terras para a agricultura. 


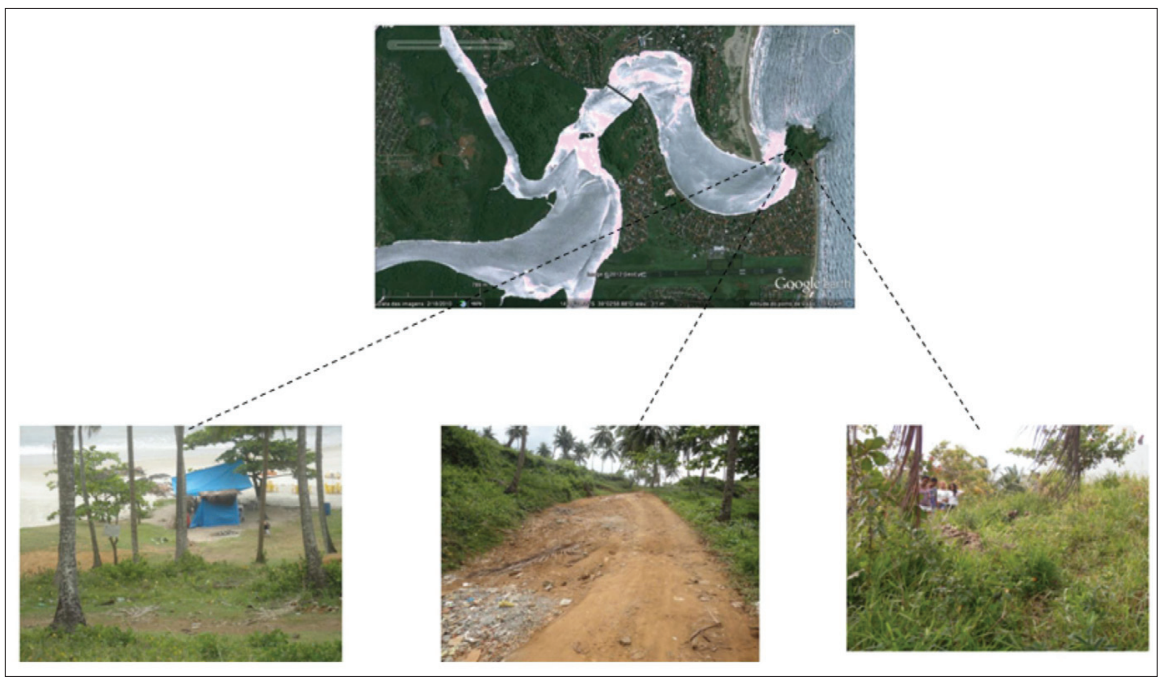

Figura 6: Cenário do Morro do Pernambuco.

Fonte: Google Earth; Emilson Batista da Silva (2012).

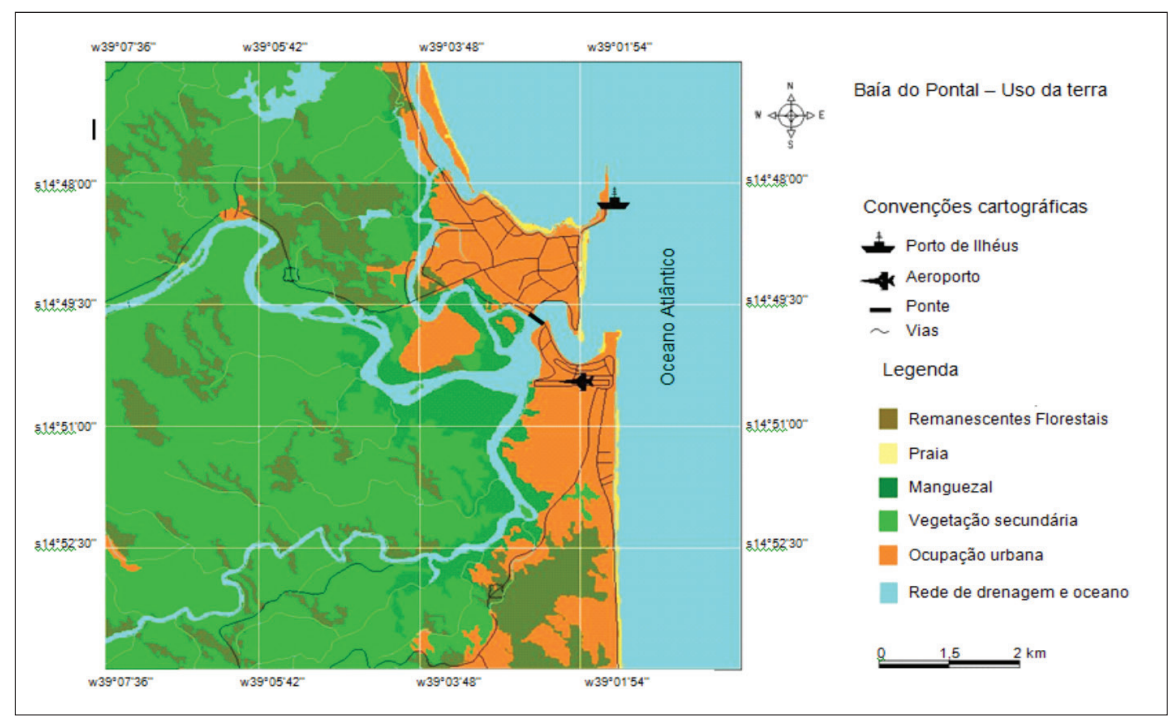

Figura 7 - Mapa de uso da terra da Baía do Pontal, 2012.

Fonte: Emilson Batista da Silva (2012). 
Destaca-se também que a queda da lavoura cacaueira contribuiu para essa situação, haja vista que, na maioria das vezes, o cacau era cultivado sobre o sistema de cabruca, isto é, o cacau era cultivado sob a sombra da Mata Atlântica.

Em grande parte da área de estudo, existe a mata secundária, juntamente com a cultura do cacau, que ainda é o principal produto econômico para o município, sendo, pois, cultivado em muitas propriedades. Caracterizada por uma constituição fitogeográfica semelhante à original, a vegetação secundária se espalha por grande parte da área de estudo, inclusive contribuindo com a composição de mata ciliar nos rios.

Como já foi frisado, a vegetação típica de manguezal encontra-se sobretudo no baixo curso dos rios tributários da Baía do Pontal. São áreas que vêm se expandindo no interior da baía, em razão do aumento do aporte de sedimento fluvial.

As praias da área de estudo são predominantemente dispersivas, ${ }^{4}$ sendo utilizadas principalmente para o desenvolvimento da atividade turística: banhos, prática de esportes, lazer e pesca. Nesses espaços, observa-se a coexistência do comércio formal e informal, que se intensifica no período de alta estação.

\section{Reflexos socioeconômicos}

Os processos que envolvem as mudanças na Baía do Pontal ecoam nos aspectos socioeconômicos, se deslocando, dessa forma, do plano biogeofísico para intervir efetivamente na vida econômica e social da cidade de Ilhéus.

No caso da Praia do Cristo, a progradação da faixa de areia e o desenvolvimento da restinga, aliados à falta de iluminação e a inexistência de infraestrutura, propiciaram um ambiente favorável à criminalidade, sobretudo à noite. Esses fatos tornam esse local uma área de baixa atração turística. Em geral, os visitantes se restringem a uma breve parada para tirar fotografias junto a um monumento chamado de Cristo (Figura 8).

Na porção sudeste, a extinção da Praia do Pontal acabou com uma importante área de lazer da população dos bairros adjacentes. Nesse local, a construção de uma contenção para a proteção da Avenida Lomanto Junior ocanionou a presença de roedores e insetos, o que limita o desenvolvimento de atividades comerciais e favorece a propagação de doenças. 


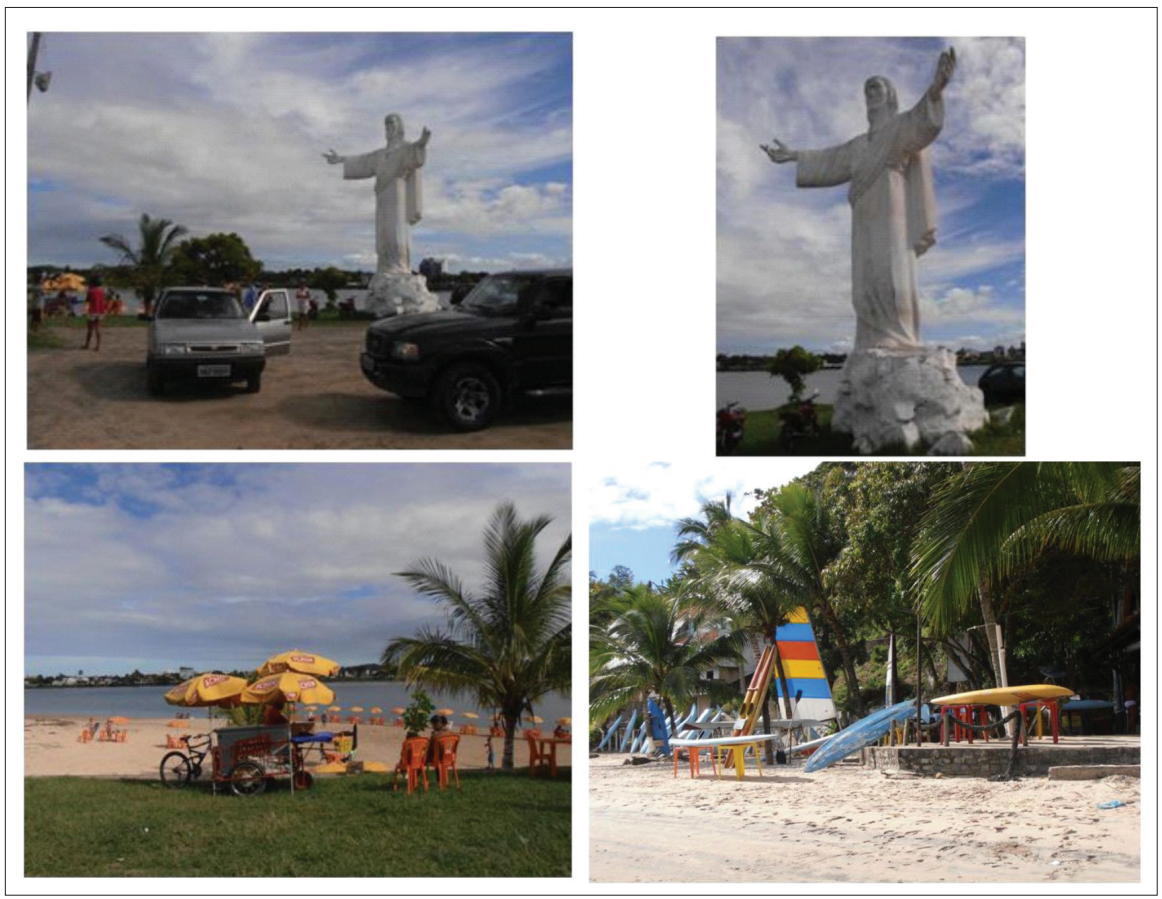

Figura 8: Praia do Cristo. Acima o monumento do Cristo.

Abaixo se observa a carência de infraestrutura.

Fonte: Emilson Batista da Silva (2012).

De acordo com moradores locais, a Baía do Pontal da década de 1950 e 1960 era muito agitada, em virtude do movimento de embarcações. Vale ressaltar que houve alguns naufrágios que ficaram registrados na memória do povo dali como, por exemplo, o do navio Nossa Senhora de Lourdes em 1957; o do Urubatan em 1959; e o do Jangadeiro em 1975. O navio Capela - a mais luxuosa embarcação que transportava passageiros para Salvador - era a embarcação mais admirada e esperada.

Os moradores afirmam que os locais para o lazer, em geral para a prática do "baba" ou banho de sol, eram a Banca do Peixe, a Alvorada, o Chafariz e a Ponta de Eustáquio. Também era comum a pesca de siri com "pelanca" de carne de boi e vísceras de frango. Os caranguejos, tão populares, eram oriundos do entorno da própria baía e preparados tradicionalmente por duas barracas de praia que existiam no local. Esse foi um 
cenário do passado que hoje só existe no imaginário dos contemporâneos dessa época.

Vale lembrar que a propagação dos mangues no entorno da baía provoca o aumento do odor, pelas características pedológicas e da vegetação desse ecossistema. Além disso, o desenvolvimento dos mangues tem se constituído em um obstáculo para a contemplação e para o acesso à baía pelos turistas, fato este que motivou a sua retirada em algumas partes da baía.

Todos esses fatos são oriundos do processo de assoreamento, que também limita o acesso de barcos a algumas áreas, inclusive considerando também o rio Cachoeira, que era navegável até o bairro do Banco da Vitória - cinco quilômetros depois de sua foz. Por isso, a prática de alguns esportes náuticos não é recomendada na baixa-mar.

É importante destacar ainda o grau de poluição das águas da baía, pois a grande quantidade de efluentes lançados em todo o sistema, considerando a baía e seus rios tributários, comprometeu a qualidade da água de tal forma que os poucos praticantes de natação que ainda se arriscam a nadar ali só o fazem na preamar. Além disso, também diminuiu sobremaneira a quantidade de pescadores na baía. Dos muitos que pescavam com tarrafas, hoje restaram alguns que tentam tirar algum sustento com seus anzóis e outros que pescam por lazer.

Esse fato também repercute na realização dos grandes eventos na cidade, como a etapa do Campeonato Mundial de Triátlon e a Travessia Ilhéus-Pontal, que eram realizados anualmente e hoje se restringem a raríssimos momentos.

Nesse sentido, a problemática instalada no estuário da Baía do Pontal tem repercussão no cenário socioeconômico do município de Ilhéus. A princípio, a população local ainda não despertou para a questão, exceto aqueles que têm um contato maior com esse espaço, como os pescadores das imediações, os que vêm do bairro do Banco da Vitória, os pesquisadores dessa temática e as pessoas mais idosas, que conviveram com a baía de outrora.

\section{Considerações finais}

O contexto analisado evidencia os reflexos das forças produtivas da sociedade na evolução natural do ambiente da Baía do Pontal. Em de- 
corrência disso, esse ambiente apresenta atualmente transformações que ameaçam seu equilíbrio dinâmico e evidenciam impactos naturais, sociais e econômicos.

As alterações são oriundas de três fatos: as intervenções nas bacias dos rios tributários, modificando a qualidade e o aporte de água doce na baía; a construção do Porto de Ilhéus, alterando a corrente de Riva litorânea e, consequentemente, a ação marinha no interior da Baía, contribuindo para o assoreamento; e o processo de ocupação do entorno da baía, haja vista que o adensamento populacional vem aumentando a pressão sobre o ambiente, em razão da carência de infraestrutura adequada, o que se desdobra em depósito de esgoto in natura no ambiente.

Esses fatos têm intensificado as forçantes naturais, que refletem em alterações na morfogênese (progradação e extinção de faixas de areia); na pedologia (surgimento de solos lamosos); na vegetação (propagação dos mangues e surgimento de restingas); e na qualidade da água (mudanças físico-químicas). Além disso, com essas transformações, a Baía do Pontal já não é utilizada para o lazer com a mesma intensidade de outrora, o que interfere na questão econômica local, haja vista que o município vê no turismo uma opção para sua economia.

Em virtude dessa conjuntura, a Baía do Pontal tende a evoluir para mais processos de profundas transformações, ameaçando o ecossistema estuarino e o potencial turístico desse ambiente. Por isso, existe a necessidade da assunção de enfrentamentos que amenizem essas intervenções e contribuam para restaurar o Estado de equilíbrio dinâmico da baía.

\section{Notas}

1. Termo que se refere a uma categoria analítica do Modelo Pressão-Estado-Resposta. São as condições atuais do estuário e refere-se aos aspectos associados aos elementos físicos (OCDE, 1993).

2. Referem-se a uma categoria analítica do Modelo Pressão-Estado-Resposta. Constituem as transformações decorrentes das atividades humanas no estuário. São os imputs representados pelas intervenções socioespaciais (OCDE, 1993).

3. Progradação: Processo de expansão da faixa arenosa da praia, devido ao acúmulo de sedimentos marinhos.

4. Praias dispersivas: praias largas com inclinação suave e granulometria fina. 


\section{Referências}

APOLUCENO, D. de M. A influência do Porto de Ilhéus (BA) nos processos de acresção/ erosão desenvolvidos após sua instalação. Dissertação (Mestrado) Instituto de Geociências, Universidade Federal da Bahia, Salvador, 1998.

CAMERON, W. M; PRITCHARD, D. W. Estuaries. In: HILL, M. N. The sea: ideas and observations on progress in the study of the seas. New York: Interscience, 1963. p. 306-324.

CORRÊA, C. da S. Tipologia morfodinâmica de sistemas praiais condicionados por diferentes níveis de energia de onda e características granulométricas: Costa das Baleias e Costa do Cacau (BA). Dissertação (Mestrado em Geologia) - Universidade Federal da Bahia, Salvador, 2010.

CRONIN, L. E. The role of man in estuarine processes. In: LAUFF, G. H. Estuaries. Washington, D.C.: American Association for the Advancement of Science, 1967. p. 667-689.

DIRETORIA DE HIDROGRAFIA E NAVEGAÇÃO (DHN). Porto de Ilhéus (Rio Cachoeira). Rio de Janeiro: Marinha do Brasil, n. FB 1201-004/76. Escala 1:5.000, 1976.

FARINACCIO, A.; TESSLER, M. G. Avaliação de impactos ambientais no meio físico decorrentes de obras de engenharia costeira: uma proposta metodológica. Revista da Gestão Costeira Integrada, v. 10, n. 4, p. 419-434, 2010.

FRANCO, G. B.; LAVENÈRE-WANDERLEY, A. A. de O.; MOREAU, N. S. Estudo comparativo da batimetria (1941-1976) da Baía do Pontal, em Ilhéus (BA). Programa de Pós-graduação em Geografia. Caminhos de Geografia, v. 7, n. 18, p. 37-46, jun. 2006. Revista on-line disponível em: <http://www.ig.ufu.br/revista/ caminhos.html>. Instituto de Geografia UFU.

ILHÉUS. 468 anos de tradição. Jornal Agora, Ilhéus, jun. 2002.

Projeto Orla: Plano de Gestão Integrada da Orla Marítima. 2007. Disponível em: <http://www.iesb.org.br/biblioteca/Projeto Orla Ilheus final. pdf $>$. Acesso em: 17 mar. 2012.

LACERDA, A. F. et al. Fragilidade ambiental e ação antrópica no entorno Baía do Pontal, Ilhéus (BA). In: VI SIMPÓSIO NACIONAL DE GEOMORFOLOGIA. Goiânia, 6 a 10 de setembro de 2006.

MARQUES, Al. C. Bacia Hidrográfica do Rio Santana: influência das atividades antrópicas na dinâmica hidrológica. Dissertação (Mestrado) - Programa Regional de Pós-Graduação em Desenvolvimento e Meio Ambiente (Prodema), Universidade Estadual de Santa Cruz, Ilhéus (BA), 2008.

MIRANDA, L. B. de; CASTRO, B. M. de; KJERFVE, B. Princípios de oceanografia física de estuários. São Paulo: Ed. USP, 2002.

NASCIMENTO, L. do et al. Deriva litorânea ao longo da Costa do Cacau, Bahia: repercussões na geomorfologia costeira. Instituto de Geociências, UFRGS, Porto Alegre (RS). Brasil Revista Pesquisas em Geociências, v. 34, n. 2, p. 45-56, 2007. 
ORGANIZATION FOR ECONOMIC COOPERATION AND DEVELOPMENT (OCDE). Organization for economic cooperation and development: core set of indicators for environmental performance reviews; a synthesis report by the group on the state of the environment. Paris: OCDE, 1993.

PEREIRA, L. C. C. et al. Efeitos de estruturas de proteção costeira nas praias da Casa Caiada e Rio Doce (PE), Brasil. Recife: Universidade Federal de Pernambuco, 1996.

PRITCHARD, D. W. Salinity distribution and circulation in the chesapeake bay estuarine system. Journal of Marine Research, v. 11, n. 1, p. 106-123, 1952.

SANTANA, S. O. de et al. Zoneamento agroecológico do município de Ilhéus, Bahia, Brasil. Ilhéus, CEPLAC/CEPEC. Boletim Técnico, n. 186, 2003.

SILVA, E. B. da. Processo de assoreamento na Baía do Pontal: causas e consequências. Monografia, Curso de Geografia, Universidade Estadual de Santa Cruz, UESC, Ilhéus (BA), 2001.

SOUZA, P. F. R. do. Circulação hidrodinâmica na região costeira dos municípios de Recife e Jaboatão dos Guararapes durante o verão austral. Dissertação (Mestrado) - Universidade Federal de Pernambuco, Recife, 2007.

SMITH, N. Desenvolvimento desigual: natureza, capital e a produção do espaço. Rio de Janeiro: Bertrand Brasil, 1988.

SPERLING, M. V. Princípios do tratamento biológico de águas residuárias: introdução à qualidade das águas e ao tratamento de esgotos. 2. ed. Belo Horizonte: DESA/UFMG, 1996.

TOURINHO, N. R. Porto de Ilhéus. Rio de Janeiro: Imprensa Nacional, 1943.

WHITEHEAD, A. N. An enquiry concerning the principles of natural knowledge. Cambridge: Cambridge University Press, 1919.

Emilson Batista da Silva - Possui Graduação e Especialização em Geografia pela Universidade Estadual de Santa Cruz. Mestrado em Geografia pela Universidade Federal da Bahia. Atualmente é Professor do Instituto Federal de Educação, Ciência e Tecnologia Baiano e do Ensino Básico da Rede Estadual de Educação da Bahia.

Recebido para publicação em 28 de novembro de 2014 Aceito para publicação em 12 de janeiro de 2015 